\title{
A Silent Epidemic of Environmental Metal Poisoning?
}

\author{
Jerome O. Nriagu \\ National Water Research Institute, Box 5050, Burlington, \\ Ontario L7R 4A6, Canada
}

\begin{abstract}
The main objective of this paper is to provoke and stimulate debate on the health effects of long-term, low-level exposure of human populations to toxic metals. Over one billion $\left(10^{9}\right)$ human guinea pigs are now being exposed to elevated levels of toxic metals and metalloids in the environment. The number of persons suffering from subclinical metal poisoning is believed to be several million. A large portion of the cases are in developed countries but the urban areas of developing countries have become 'hot-spots' of metal pollution, and the populations of such countries are particularly susceptible to environmental toxins. As a global problem, the potential health effects of metallic hazards should be a matter of public health concern, especially if the emissions of toxic metals into the environment continue at the current rate.
\end{abstract}

\section{INTRODUCTION}

Metals and their compounds are indispensable to the safety and economy of most nations and have been key factors in the liberation of modern civilization from hunger, disease and discomfort. Few, if any, of the metals known to mankind have not found some application in industry, and the number of commercial uses continues to grow with the development of modern science and technology. Inevitably, each industrial process generates wastes which must be discharged into the environment, along with the ever growing list of new metallic compounds. It has been estimated that the toxicity of all the metals being released annually, into the environment, 139

Environ. Pollut. 0269-7491/88/\$03.50 (C) Elsevier Applied Science Publishers Ltd, England, 1988. Printed in Great Britain 
far exceeds the combined total toxicity of all the radioactive and organic wastes, as measured by the quantity of water needed to dilute such wastes to the drinking water standard (Nriagu and Pacyna, in press). Pollutant metals are non-degradable and the continuing build-up of such toxins in mankind's life-support systems has to be of some health concern.

This report advances the provocative view that the current levels of toxic metals in some environmental compartments may be high enough to constitute a threat to human health. Some may argue that such a proposition cannot be substantiated by hard scientific data. Nevertheless, it is incontestible that each environmental compartment has a limited carrying capacity for metal pollution, and, with enough time, the current rates of metal inputs will become stressful to many ecosystems. My primary aim is to provoke and stimulate further discussions on the present and future health implications of long-term exposure of mankind to elevated environmental levels of metals. This very profound experiment, in which one billion $\left(10^{9}\right)$ human guinea pigs are being exposed to undue insults of toxic metals, has yet to receive the scientific attention that it clearly deserves.

\section{SOURCES OF TRACE METALS IN THE ENVIRONMENT}

Trace metals are released into the environment from a wide spectrum of natural and anthropogenic sources (Nriagu, 1978; Moore and Ramamoorthy, 1984; Adriano, 1986). The principal anthropogenic sources of trace metals in the atmosphere, however, are smelting of metallic ores, industrial fabrication and commercial applications of metals, as well as burning of fossil fuels (Table 1). Lead and arsenic are notable exceptions, the principal sources of these elements being the use of leaded gasoline and the spraying of arsenic pesticides. Metal pollution in soils is derived mostly from atmospheric fallout, coal fly ash and bottom ash, urban refuse, animal wastes, and agricultural and food wastes (Table 1). On the other hand, the principal sources of pollutant metals in natural waters are the discharge of domestic and industrial (including mine and smelter) waste-waters and the dumping of sewage sludge (Table 1). For most metals, the order of magnitudes of input is soil $>$ water $>$ air. Although considerable attention has been paid to the atmospheric cycle of the trace elements (see, for example, Nriagu and Davidson, 1986), much less has been done to understand the fate and effects of metal pollution in soils and natural waters.

Since the turn of this century, the ever-expanding technological development has resulted in the consumption of huge quantities of trace metals (Table 2). Between 1930 and 1985, the mine production of $\mathrm{Al}, \mathrm{Cr}, \mathrm{Cu}$, $\mathrm{Ni}$ and $\mathrm{Zn}$ increased by 114-, 18-, 5-, 35- and 4-fold, respectively. The point 
A silent epidemic of environmental metal poisoning?

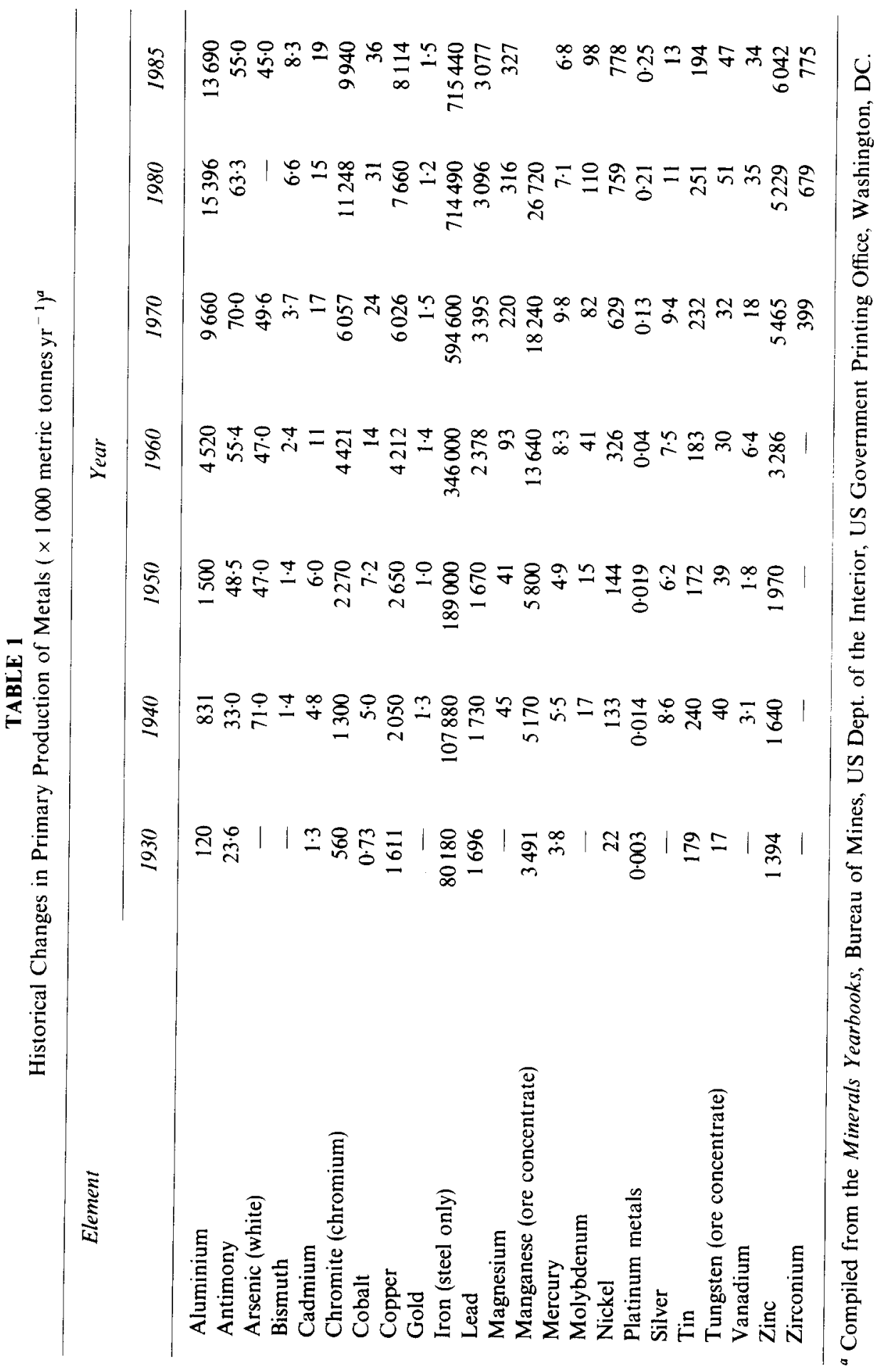


TABLE 2

Global Emissions of Trace Metals into the Atmosphere, Water and Soil (in 1000 metric tonnes $\left.\mathrm{yr}^{-1}\right)^{a}$

\begin{tabular}{lccc}
\hline \multicolumn{1}{c}{ Element } & Air & Water & Soil \\
\hline Arsenic & $18 \cdot 8$ & 41 & 82 \\
Cadmium & $7 \cdot 6$ & $9 \cdot 4$ & 22 \\
Chromium & 30 & 142 & 896 \\
Copper & 35 & 112 & 954 \\
Mercury & $3 \cdot 6$ & $4 \cdot 6$ & $8 \cdot 3$ \\
lndium & $0 \cdot 02$ & - & - \\
Manganese & 38 & 262 & 1670 \\
Molybdenum & $3 \cdot 3$ & 11 & 88 \\
Nickel & 56 & 113 & 325 \\
Lead & 332 & 138 & 796 \\
Antimony & $3 \cdot 5$ & 18 & 26 \\
Selenium & $3 \cdot 8$ & 41 & 41 \\
Tin & $6 \cdot 4$ & - & - \\
Thallium & $5 \cdot 1$ & - & - \\
Vanadium & 86 & 12 & 132 \\
Zinc & 132 & 226 & 1372 \\
\hline
\end{tabular}

${ }^{a}$ From Nriagu and Pacyna (in press).

that needs to be emphasised is that the mine-produced metals will ultimately be wasted in the biosphere; on a cumulative basis, the quantity of toxic metals dispersed in this way is considerable.

Trace metals are omnipresent in the environment, occurring in varying concentrations in air, bedrock, soil, water and all biological matter (Bowen, 1979). In pretechnological times, the cycling of each trace metal was basically at a steady state and a tight control was maintained on its distribution in any given ecosystem. Calculations using the data in Table 1 strongly suggest that the anthropogenic inputs have now overwhelmed the natural biogeochemical cycles of trace metals in many ecosystems (see also, Andreae et al., 1984). The implication is clear: the greatly increased circulation of toxic metals in soils, air and water, results in the inevitable build-up of such toxins in the human food chain. The increased environmental exposure is implicated in the well-documented elevations in the concentrations of several trace elements in body fluids and organ systems of contemporary populations (Patterson, 1980; Drasch, 1983). Some of the toxic metals (specifically $\mathrm{Pb}, \mathrm{Cd}$, $\mathrm{Hg}, \mathrm{Tl}$ and $\mathrm{Ag}$ ) have no beneficial effects in humans and there is no known homeostasis mechanism for them. Any long-term exposure may therefore be expected to progressively cause more severe disruptions in the normal functioning of the organ systems where the metals are accumulating. 


\section{SIGNS OF ENVIRONMENTAL METAL POISONING}

Current environmental levels of toxic metals rarely produce morbidity or death in the general population. The first step in this discussion, therefore, must address the basic definition of an adverse health effect. Many years ago, the World Health Organization defined health as 'a state of complete physical, mental, and social well-being, and not merely the absence of disease or infirmity' (Callahan, 1977). More recently, Sherwin (1983) defined health as 'the homeostasis of the cellular ecology, and a state where there has not been an inordinate loss, reversible or irreversible, of the structural and/or functional reserves of the body'. He defined an adverse health effect as 'the causation, promotion, facilitation, and/or exacerbation of a structural and/or functional abnormality, with the implication that the abnormality produced has the potential of lowering the quality of life, contributing to a disabling illness, or leading to a premature death'. I have adopted Sherwin's definition, which, by analogy with the impacts of contaminants on ecosystem health, implies that a large segment of the 'well population' can be suffering from metal poisoning without even realising it.

It has been known since ancient times that the symptoms of metal toxicity are usually nonspecific and retrospective, rather than early-warning or prospective. Alterations in the vital signs become manifested only after the intoxication process has advanced to the stage where the homeostatic mechanisms can longer maintain the body functions within the accepted normal range. Within the spectrum of possible adverse health effects, environmental metal poisoning is most likely to be (a) subclinical, ranging from early lesions to nascent clinical diseases in which the patient either does not show any symptoms or fails to recognise them, and (b) hypeinopenia, or in a state of health where there has been an inordinate depletion of the functional integrity of the cell, tissue or organ.

The early biological indicators of the metal interactions with subcellular biochemical systems are usually either metabolites of the system affected (porphyrinurias, for example) or represent some specific function of the cellular system being impaired (e.g., proteinurias). With the possible exception of lead, the current level of sensitivity of clinical tests is inadequate for the diagnosis of such a subtle biochemical or so-called 'no-effect' distress syndrome.

Figure 1 illustrates the continuum in the effects of lead poisoning, from those that are distinctly adverse to those that only reduce the ability of the body to cope with other forms of toxic stress. The far ranging impact of $\mathrm{Pb}$ on haeme biosynthesis includes reductions in such functions as cellular energetics, oxygen transport, neurotransmitter functions, suppression of hepatic detoxification of certain drugs and xenobiotics, and impaired 


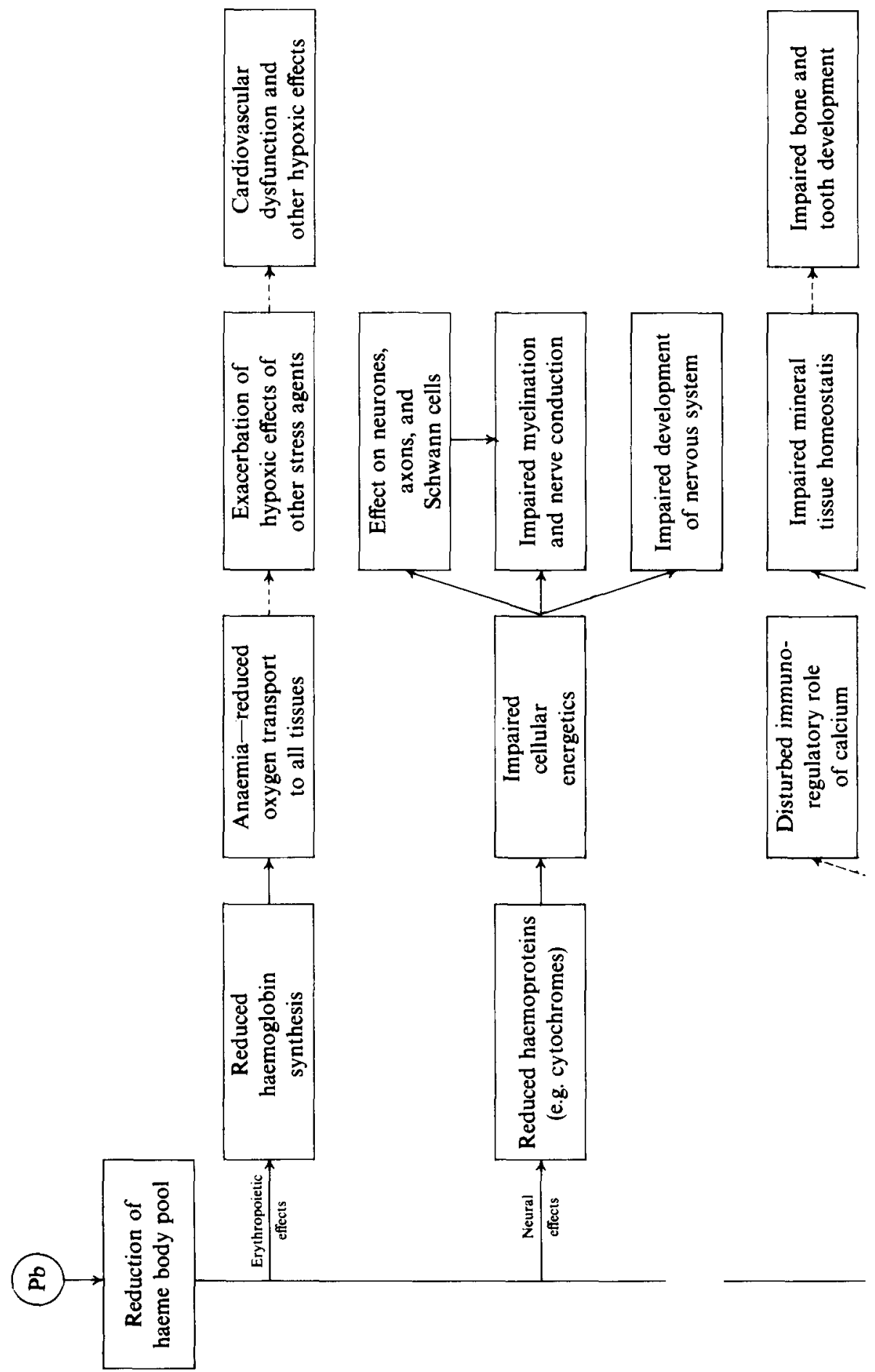




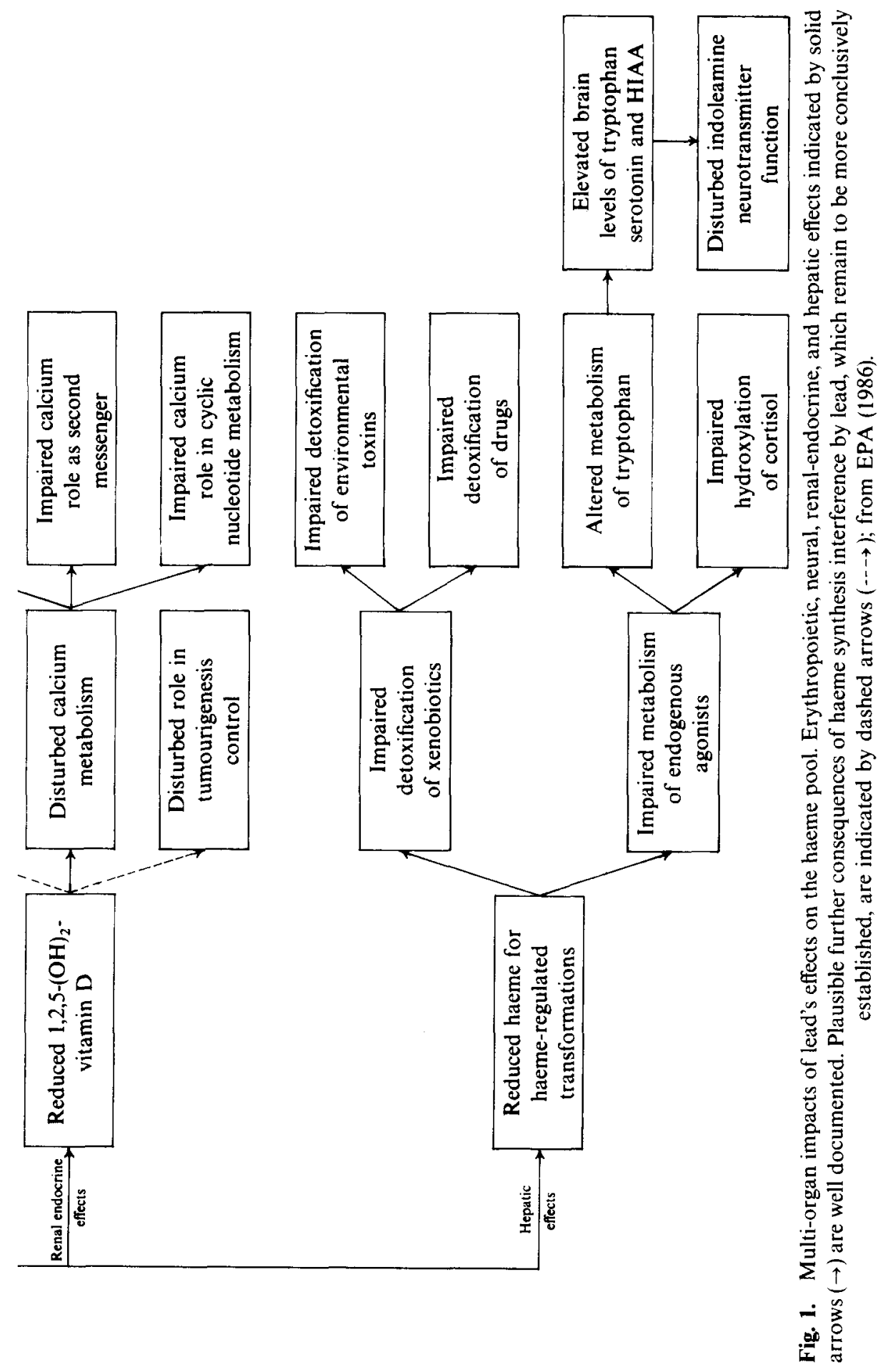


biosynthesis of such important compounds as 1,2,5-dihydroxyvitamin D (EPA, 1986). Manifestations of reduction in the reserve capacity of some organ systems have no known threshold and have been observed at blood $\mathrm{Pb}$ $(\mathrm{PbB})$ concentrations as low as $60 \mu \mathrm{glitre}^{-1}$ (EPA, 1986). In spite of recent evidence to the contrary, many health officials still apply the 'threshold health effect' concept in evaluating the health significance of particular toxicity effects and their clinical management.

It goes without saying that our understanding of the health effects of longterm exposure to low doses of metals still has a lot of loose ends. The actual form of the dose-response curve which prevails at the low levels of environmental exposure is basically unknown for most metals. There is some evidence to suggest that pollutant metals have synergistic toxicity (Fern, 1971; Wong et al., 1982) so that the risks in the low-dose, low-rate exposure region may be considerably enhanced (Zeise et al., 1987). The interactive toxicity of metals and organic contaminants has yet to be explored in the human population. As potential cofactors in other diseases, trace metals can elicit their toxicity in a disguised manner.

The impacts of industrial activities on metal levels in the environment has already been noted. The elevated baseline exposure to metals can (a) lead to gross under-estimation of the actual effects of low doses; (b) negate the usual medical assumption that the current 'normal' exposure is synonymous with the so-called 'no-effect' exposure; and (c) greatly reduce any margin of safety that might have existed in terms of particular metal intoxication.

\section{PREVALENCE OF SUBCLINICAL EFFECTS OF METAL POISONING IN THE GENERAL POPULATION}

This section deals with the available evidence on the earliest adverse health effects which can entail serious alterations in cellular ecology but may not come to clinical attention until the structural or functional damage has reached an end-stage. It is based on the definition of an adverse health effect as previously defined. In this connection, it should be re-emphasised that medical diagnosis is still bedevilled by conflicting claims on the significance that should be attached to some of the early biological signs of subclinical poisoning by metals. Actual experimental verification of the long-term health effects of low-level exposure to toxic metals remains difficult (human subjects are rarely candidates for study) and expensive. Epidemiological studies usually estimate the probability of health effects based on the interpretation of experimental and statistical data. The researcher's preconceptions and predispositions, as well as differences in the experimental protocols, all come into play in the interpretation of the data. Also, 
the debate becomes no more rational when the key issue is economic benefits versus risks of exposure to environmental levels of trace metals. It should be obvious that the following assessment of the worldwide risks of metal poisoning is far from being universally accepted.

\section{Lead poisoning}

Environmental exposure to low levels of lead has been associated with a wide range of metabolic disorders and neuropsychological deficits (NAS, 1980; EPA, 1986). The well-known toxic (metabolic and cellular) effects of lead in asymptomatic children include (i) impairments in haeme, vitamin D and red blood cell nucleotide metabolism, (ii) perturbations of calcium homeostasis in the hepatocytes, bone cells and brain cells, and (iii) neurological damage (Rosen, 1985; Lansdown and Yule, 1986). Although many of the biochemical and neurological changes associated with lead toxicity have been observed at $\mathrm{PbB}$ concentrations as low as $60 \mu \mathrm{glitre}^{-1}$ (Table 3), the threshold for possible medical intervention has been set at 250-300 $\mu$ glitre $^{-1}$ (CDC, 1985).

TABLE 3

Lowest Observed Blood Lead Concentrations Associated with Lead-Induced Metabolic Changes (Health Effects?) in Children ${ }^{a}$

\begin{tabular}{lc}
\hline \multicolumn{1}{c}{ Effect } & $\begin{array}{c}\text { Blood lead concentration } \\
\text { when first observed } \\
\left(\mu \text { glitre }^{-1}\right)\end{array}$ \\
\hline Inhibition of erythrocyte ALA-D & $<40-60$ \\
Inhibition of vitamin D metabolic processes & $40-60$ \\
IQ deficits & $\sim 60$ \\
Hearing loss & $\sim 60$ \\
Perinatal changes in haeme metabolism & $80-100$ \\
Inhibition of Py-5-N $\mathrm{N}^{\mathrm{c}}$ and ALA-D activity & $<100$ \\
Impairment of post-natal growth and development & $<100$ \\
$\quad$ Elmental and physical) & $\sim 150$ \\
$\quad$ blood cells & $\sim 150$ \\
Increased levels of ALA in blood and soft tissues & $\sim 150$ \\
Changes in electrophysiological functioning of & $\sim 150$ \\
$\quad$ the nervous systems & 200 \\
Reduction in nerve conduction velocity &
\end{tabular}

${ }^{a}$ Data mostly from EPA (1986) and Levin (1987).

${ }^{b} \mathrm{ALA}=$ aminolevulinic acid.

${ }^{c}$ Py-5-N = pyrimidine-t'-nucleotidase. 
A nationwide survey in the USA done between 1976 and 1980 found that $3.5 \%$ of children under the age of 5 had $\mathrm{PbB}$ levels of $300 \mu \mathrm{g}$ litre ${ }^{-1}$ or more (DHHS, 1982), which is well above the medical intervention threshold. The total number of school children was about 16.9 million, implying that about 590000 children in the country between the ages of 6 months and 5 years are over-exposed to lead and may be suffering from lead poisoning. There was a marked racial difference in the lead risk, with about $10.2 \%$ (or about 264000 ) of black children and only $1.8 \%$ of white children showing elevated $\mathrm{PbB}$ levels (Table 4). Also, about $0.5 \%$ of the children aged 6-17 and 1.8 of the adult population in the 18-74 age group had $\mathrm{PbB}$ in excess of $300 \mu \mathrm{g} \mathrm{litre}^{-1}$ (Table 4). When the threshold $\mathrm{PbB}$ concentration is lowered to $200 \mu \mathrm{g} \mathrm{litre}^{-1}$ (still well above the limit for many health effects, see Table 3), the number of pre-school children at risk increases to 3.5 million, with black children accounting for about $30 \%$ of this total. For all age groups, the number of people at risk is over 26 million at the $200 \mu \mathrm{g}$ litre ${ }^{-1} \mathrm{PbB}$ threshold (Table 4). In recognition of the magnitude of this national health issue in children (black, white, poor, rich, city or countryside), the US Environmental Protection Agency has concluded that 'there is a national health problem associated with exposure to environmental lead for the general population and, in particular, pre-school children' (EPA, 1986). The Center for Disease Control in the United States now recommends that all children of 9 months to 6 years of age should be screened for lead at least once annually.

The distribution of $\mathrm{PbB}$ concentrations in the populations of Western Europe and Australia is similar to that of the United States (EPA, 1986; Lansdown and Yule, 1986). On the other hand, higher PbB concentrations have been reported in some urban populations in developing countries (WHO, 1977; Lansdown and Yule, 1986). Thus, extrapolation of the USA data to urban areas of other countries may not be very realistic. If the threshold concentration for health effects is set at $200 \mu \mathrm{g} \mathrm{litre}^{-1} \mathrm{PbB}$, the total number of over-exposed people at great risk of being poisoned is estimated to be about $130-200$ million, assuming that only $20-30 \%$ of the human population (of $5 \times 10^{9}$ ) living in urban areas have the $\mathrm{PbB}$ distribution similar to the general population of the United States (see Table 4). At the $300 \mu \mathrm{g}$ litre ${ }^{-1}$ threshold, the number of school children (about $10 \%$ of the population) at greatly increased risk of being poisoned by lead is estimated to be 5-7 million. Even if only a small fraction of the persons at risk experience some health impairment, the fact remains that lead poisoning must be regarded as the most prevalent public health problem in many parts of the world.

The figures above are for people already overburdened by lead as determined by their $\mathrm{PbB}$ concentrations. On a global scale, the actual number of people exposed to elevated environmental $\mathrm{Pb}$ levels which can 
A silent epidemic of environmental metal poisoning?

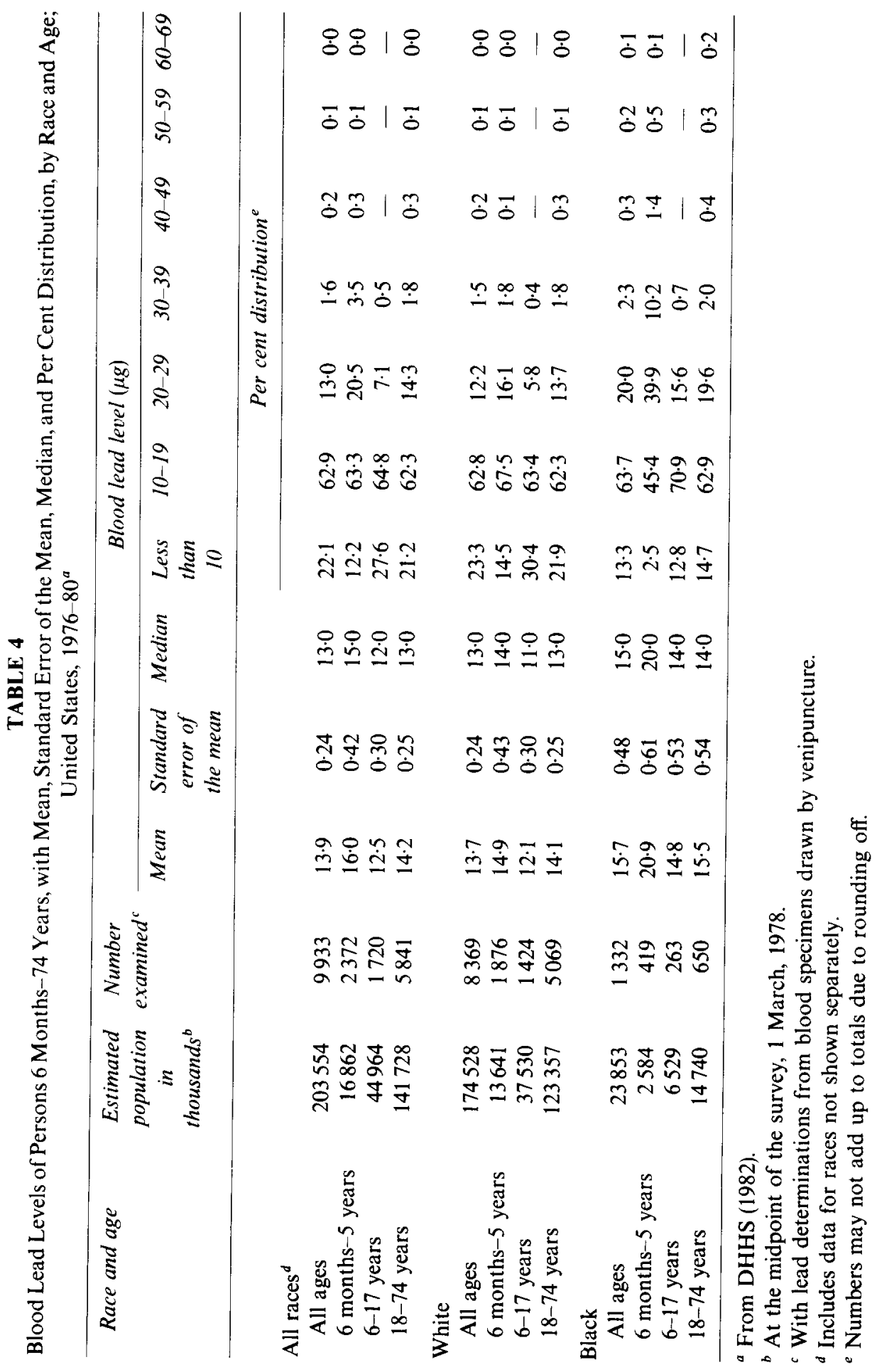


result in $\mathrm{PbB}$ concentrations of $200 \mu \mathrm{glitre}^{-1}$ or more, is well over one billion. For example, Levin (1987) has estimated the number of people in the USA exposed to drinking water with a Pb concentration above $20 \mu \mathrm{glitre}^{-1}$ is about 42 million; it is believed that exposure to $20 \mu \mathrm{g}$ litre ${ }^{-1} \mathrm{~Pb}$ in drinking water can result in $\mathrm{PbB}$ concentrations above $150 \mu \mathrm{glitre}^{-1}$. Levin's

TABLE 5

Summary of Estimated Annual Non-Monetised Benefits of Reducing Exposure to Lead from $50 \mu \mathrm{g} \mathrm{litre}^{-1}$ to $20 \mu \mathrm{g} \mathrm{litre}^{-1}$ for Sample Year $1988^{a}$

\begin{tabular}{|c|c|}
\hline & $\begin{array}{l}\text { Reduction in numbers } \\
\text { of people at risk }\end{array}$ \\
\hline \multicolumn{2}{|l|}{$\begin{array}{l}\text { Estimated population exposed to } \\
\text { drinking water exceeding proposed } \mathrm{MCL}\end{array}$} \\
\hline \multicolumn{2}{|l|}{ Children's health benefits } \\
\hline Children requiring medical treatment & 29000 \\
\hline Loss of $1-2$ IQ points & 230000 \\
\hline 4 IQ points & 11000 \\
\hline $5 \mathrm{IQ}$ points & 100 \\
\hline Children requiring compensatory education & 29000 \\
\hline Children at risk of stature decrement & 82000 \\
\hline Foetuses at risk & 680000 \\
\hline Increased risk of haematological effects & 82400 \\
\hline \multicolumn{2}{|l|}{ Adult health benefits } \\
\hline $\begin{array}{l}\text { Cases of hypertension } \\
\text { (males, aged 40-59) }\end{array}$ & 130000 \\
\hline $\begin{array}{l}\text { Heart attacks } \\
\quad(\text { white males, aged } 40-59)\end{array}$ & 240 \\
\hline $\begin{array}{l}\text { Strokes } \\
\quad(\text { white males, aged } 40-59)\end{array}$ & 80 \\
\hline $\begin{array}{l}\text { Deaths } \\
\text { (white males, aged 40-59) }\end{array}$ & 240 \\
\hline $\begin{array}{l}\text { Reduced risk to pregnant women } \\
\text { (women, aged 15-44 (same as foetuses)) }\end{array}$ & 680000 \\
\hline
\end{tabular}

estimates of the number of children, nubile women and adult males at increased risk of experiencing various adverse health effects due to the lead in their drinking water (Table 5) should be disconcerting to some public health officials. In addition, drinking water represents only a minor route of $\mathrm{Pb}$ exposure for the human population in the United States (Mahaffey et al., 1982). 


\section{Cadmium poisoning}

One of the early signs of Cd intoxication of the kidney is tubular proteinuria, or the excretion of low molecular weight proteins and retinol-binding proteins (Nomiyama, 1981; Friberg et al., 1984/85). This form of proteinuria, however, is not always specific for $\mathrm{Cd}$ and may be found in other forms of renal dysfunction. The currently known 'early warning signs' of cadmiuminduced cellular damage and loss of reserves (or vitality) are thus poor, making it difficult to estimate the actual number of people with subclinical Cd poisoning.

The release of $\mathrm{Cd}$ from numerous non-ferrous metal mines and smelters has resulted in $9.5 \%$ of paddy soils, $3.2 \%$ of upland soils and $7.5 \%$ of orchard soils in Japan being severely contaminated with Cd (Asami, 1984). Food crops, especially rice, grown in such soils, are also contaminated with this metal. As a result, the dietary intake of $\mathrm{Cd}$ (about $56 \mu \mathrm{g}$ per day) and the average $\mathrm{Cd}$ concentration in renal cortex $\left(60-100 \mu \mathrm{g} \mathrm{g}^{-1}\right)$ in the Japanese population (Tsuchiya, 1976; Friberg and Vahter, 1983; Piscator, 1985) currently leave little safety margin for many residents. Renal Cd concentrations close to the critical value of $200 \mu \mathrm{g} \mathrm{g}^{-1}$ and daily Cd intakes of $70 \mu \mathrm{g}$ are occasionally exceeded, even in the unpolluted areas (Friberg and Vahter, 1983). As to be expected, many elderly multiparous women with poor nutritional habits who live in the contaminated areas of Japan, and elsewhere, now show signs of renal dysfunction (Roels et al., 1981; Nogawa, 1984).

Metabolic models (Kjellstrom and Nordberg, 1978) suggest that the average daily intake of $100-180 \mu \mathrm{g} \mathrm{Cd}$ per day by residents in the highly polluted areas of Japan, can lead to excessive renal Cd accumulation in about $5-10 \%$ of the people so exposed. On the other hand, the intake rate of $42-69 \mu \mathrm{g}$ per day in the 'unpolluted' areas (Nogawa, 1984) can place $0 \cdot 5-1 \%$ of the population above the critical level $\left(200 \mu \mathrm{g}\right.$ litre $\left.{ }^{-1}\right)$ over an extended period of time. An average daily intake of $32 \mu \mathrm{g} \mathrm{Cd}$, which is typical of many countries (Hutton, 1982; Friberg and Vahter, 1983), can result in $0.1 \%$ of the population having $\mathrm{Cd}$ concentrations in the renal cortext above the $200 \mu \mathrm{g} \mathrm{g}^{-1}$ threshold for proteinuria (Piscator, 1985). If it is assumed that only $5-10 \%$ of the human population actually ingest this amount of $\mathrm{Cd}$, the number of persons likely to accumulate $\mathrm{Cd}$, possibly to the stage of renal dysfunction, is estimated to be 250000-500000. This number pertains to the background occurrence of parasthesia, and the number actually at risk is probably considerably higher. Most of the people presently at risk from environmental Cd poisoning are believed to be in Japan and central Europe where the soils have become contaminated with this element (Asami, 1984; Kloke et al., 1984). 


\section{Mercury poisoning}

There are currently no known biochemical indicators of cellular distress associated with mercury poisoning. Screening for chronic $\mathrm{Hg}$ poisoning is not always feasible and the clinical symptoms of acute poisoning in the general population are equivocal (Clarkson, 1984).

It has been estimated that the number of persons in Japan certified or suspected of having $\mathrm{Hg}$ poisoning is about 8000 (Asami, 1984). On a worldwide scale, the number afflicted with $\mathrm{Hg}$ intoxication may be assumed to be 5-10 times the number of cases in Japan, or approximately 40000 to 80000 individuals. Since the consumption of fish and seafoods is the primary exposure route for $\mathrm{Hg}$ (specifically methylmercury), most of the stricken people are likely to be found in small fishing villages around the world.

\section{Arsenic poisoning}

The most important environmental route of As exposure is contaminated drinking water, especially groundwater. In general, As is derived from natural sources but in some cases mining activities have been implicated (Buat-Menard et al., 1987).

There are few, if any, early biochemical warning signs of chronic As poisoning and clinical symptoms have to be used to measure the acute health effects. Epidemiological investigations in many parts of Europe, North and South America, and Asia have demonstrated a close association between As exposure and various skin disorders, including skin cancer (WHO, 1981; Pershagen, 1983).

In the most detailed of the epidemiological studies done in Taiwan, Tseng (1977) found a very strong positive correlation between As intake from drinking contaminated water, and both skin cancer and the peripheral vascular disorder known as 'blackfoot' disease. The prevalence rates for skin cancer, hyperpigmentation and keratosis were about 11,184 and 71 per 1000 in the survey of 40000 people, out of the total exposed population of 100000 persons. When a dose-response model was applied to the Taiwan data and the curve extrapolated to environmental levels, it was predicted that the lifetime risk of skin cancer from drinking water with only $2 \mu \mathrm{g} \mathrm{litre}^{-1}$ As would be 1 per 1000 (Calabrese, 1983). If this prediction were to approximate reality, the number of persons in endemic areas at risk of contacting arsenicinduced skin cancers would clearly run into hundreds of thousands. As a matter of fact, well over 250000 people in Chile were exposed for several decades to As concentrations in drinking water which were considerably higher than the level known to cause skin disorders (WHO, 1981). In 
addition, no one can say with certainty that a situation like that does not exist in some parts of developing countries, for example, in China (see BuatMenard et al., 1987). In an area with contaminated groundwater, the added exposure to As from environmental sources will further erode the margin of safety for the unaffected segment of the population.

\section{Poisoning by other metals}

The preceding discussions have dwelt on the 'big four' toxic metals of environmental concern. Table 1 , however, shows that many other toxic metals and metalloids are also released in large quantities into the different environmental compartments. Since these metals accumulate in mammalian tissues, even at low exposure doses, they must represent an environmental health hazard. Aluminium, for example, has been implicated as a confounding factor in the aetiology of Alzheimer's disease (Perl, 1985). In itself, $\mathrm{Al}$ is not a typical 'environmental' poison, but its chemistry and toxicity are strongly influenced by the acidity of rainfall (Driscoll, 1985). Another example worth mentioning is thallium, which is released in large quantities from cement plants, with up to $2 \% \mathrm{Tl}$ observed in flue dusts (Kjellstrom et al., 1984). One suspects that a significant number of persons living within the 'hot spots' around cement factories could be adversely affected by this highly toxic element. The early warning signs of $\mathrm{Tl}$ poisoning in the general population have yet to be ascertained.

It would be a fatal mistake to presume that environmental metal poisoning is only a problem in developed countries. Some of the developing countries have become major producers of non-ferrous metals, and many industries in these countries tend to be dirtier and employ less stringent environmental control measures. In fact, the highest concentrations of $\mathrm{Pb}$ in the atmosphere are now being reported in the urban areas of the developing countries (Lansdown and Yule, 1986), and there is every indication that the environmental levels of many toxic metals will rise steadily in such parts of the world. On sociological grounds alone, populations in developing countries are likely to be more susceptible to environmental metals as a result of (i) the high population density and poor hygienic conditions in the crowded cities; (ii) the preponderance of the groups considered to be most at risk, notably children and pregnant women; (iii) poor nutritional and health status; and (iv) consumption of a high proportion of foods grown locally in metal contaminated areas. Other endemic health problems can also influence the course and severity of metal toxicity in the developing countries. 


\section{TRACE METALS AS CONFOUNDING FACTORS IN OTHER DISEASES}

In their work and play, human beings are exposed to complex mixtures of toxic substances at relatively low doses. These contaminants are now being increasingly implicated in the aetiology of a large number of our common diseases and ailments. In terms of the quantities being emitted, toxic metals must be considered as an important cofactor or confounder in some of these diseases.

\section{Cardiovascular diseases}

It has been known for a long time that a number of trace metals, notably $\mathrm{Pb}$ and $\mathrm{Cd}$, possess cardiotoxic properties and can contribute to cardiomyopathy. These metals affect the cardiovascular metabolism by acting on the renin-angiotensin, killikrein-kinin, adrenergic, and prostaglandin systems (Carmignani et al., 1983). Interference in calcium-activated processes, smooth-muscle tone, essential metal metabolism and damage to cardiac tissues can also increase the blood pressure (EPA, 1986). The possible role of metals in cholesterol accumulation is unclear.

Schroeder (1965) was the first to draw attention to the possible link between human hypertension and the concentration of $\mathrm{Cd}$ in drinking water. Since then, a number of studies have found strong correlations between hypertension and $\mathrm{Cd}$ concentrations in blood and plasma, urine, kidney cortex and other tissues (see NAS, 1979, for a good review). Higher incidence of cardiovascular diseases, including hypertension, has been reported in populations living in areas polluted with Cd (Hickey et al., 1967; Nogawa, 1981). The concentration of airborne Cd was found to be strongly correlated with hypertensive and atherosclerotic heart disease in 26 large cities in the USA (Carroll, 1966). More recently, Borella et al. (1987) found a significant positive correlation between both systolic and diastolic blood pressure levels and low environmental exposure doses of cadmium.

The role of $\mathrm{Pb}$ in human hypertension is less equivocal, mostly due to two large-scale epidemiological studies: (a) the British Regional Heart Study involving 7735 middle-aged (40-49 years old) men and (b) the Second National Health Assessment and Nutritional Evaluation Survey (NHANES II) of 10000 representatives of the non-institutionalised population of the United States. These studies provide highly convincing evidence for robust and statistically significant association between $\mathrm{PbB}$ levels and increased blood pressure in adult men (Pocock et al., 1984; Pirkle et al., 1985; Schwartz, 1986; Schwartz et al., 1984). The NHANES II study found that the relationship remains significant at $\mathrm{PbB}$ concentrations as low as 
$60 \mu \mathrm{g}$ litre ${ }^{-1}$, implying that there is no threshold for the effect of $\mathrm{Pb}$ on blood pressure. The 'no threshold effect' is supported by studies on animals which consistently find a strong positive correlation between hypertension and exposure to low $\mathrm{Pb}$ doses over relatively long periods (see EPA, 1986).

Of the millions of hypertensive subjects worldwide, how many have been affected by long-term exposure to trace metals in their environment? Levin (1987) estimated that the reduction of $\mathrm{Pb}$ in drinking water in the USA could reduce the number of cases of hypertension by 130000 (Table 5). Assuming that the worldwide case load is only 3-5 times that of the United States, the number of persons that may be afflicted is estimated to be 400000 to 650000 . It should also be of concern that there may be synergism in the cardiotoxicities of not only the trace metals themselves, but between the trace metals and organic contaminants (Murthy et al., 1975; Lewis et al., 1976; Der et al., 1976). Even if the current environmental levels are below the pressor dose (i.e. not causing a rise in arterial pressure), no one is sure what margin of safety still exists for the large number of susceptible individuals being subjected to undue trace metal insults.

\section{Reproductive impairments}

Demographic evidence strongly suggests that reproductive impairments that result in the inability to conceive, spontaneous abortion, premature birth, low birth weight, morphological and functional birth defects, and perinatal mortality are becoming more frequent and widespread (Nisbet and Karch, 1983). About $15 \%$ or more of North American couples now experience some difficulty in conceiving (Thomas, 1986), and in the United States alone about 7 million couples have been estimated to be infertile (Mosher, 1980). Estimates (made in the USA and other countries) of reproductive attempts that fail or are impaired, range from $30 \%$ to $80 \%$, the large uncertainty being due to the difficulty in establishing the frequency of conception failures and very early spontaneous abortions (Nisbet and Karch, 1983; Jackson, 1985). The declining fecundity has become a matter of some concern, especially in developed countries.

In a recent comprehensive review of chemical hazards to human reproduction, Nisbet and Karch (1983) concluded that 'The frequency of some types of reproductive impairment has changed in time, at a rate much more rapid to be explained by genetic changes or changes in other intrinsic factors .... In some cases, the frequency of various kinds of reproductive impairment can be associated statistically with various environmental factors'. They also noted that in terms of dose and effects, a close concordance exists between humans and some of the most sensitive animals.

Some trace metals are notorious foetotoxins and must be considered as 
one of the key 'environmental factors' that affect different stages in male and female reproduction. Lead, for example, is associated with a wide range of negative pregnancy outcomes, including early membrane rupture, low birth weight, spontaneous abortion, complications during pregnancy, increased perinatal mortality, inhibited postnatal growth and development, etc. (EPA, 1986). The effects on the male reproductive system include erectile dysfunction, asthenospermia, hypospermia, teratospermia and changes in semen cytology (principally sperm count, morphology and motility) (Bell and Thomas, 1980). The number of pregnant women (and foetuses) in the United States, estimated to be at risk of health effects from $\mathrm{Pb}$ in drinking water alone is close to 700000 (Table 5). On the other hand, the number of conceptions by women with $\mathrm{PbB}$ above $200 \mu \mathrm{glitre}^{-1}$ is estimated to be about 430000 assuming that nubile women (15-40 years old) comprise $24 \%$ of the USA population and that $6.7 \%$ of them are pregnant at any given time (Levin, 1987). Conceptions by women with $\mathrm{PbB}$ over $300 \mu \mathrm{g} \mathrm{litre}^{-1}$ number well over 50000 .

Other metals that can adversely affect human reproduction include As, $\mathrm{Sb}, \mathrm{Be}, \mathrm{Cd}, \mathrm{Hg}, \mathrm{Cr}, \mathrm{Co}, \mathrm{Ni}$ and $\mathrm{Al}$. These elements are also released in large quantities into the environment and may be contributing to the reproductive failures being experienced by contemporary populations.

Gene mutations and chromosome aberrations in human populations have also been linked to environmental factors. The frequency of different types of genetic disorder (including congenital anomalies and chromosomal defects) have been estimated to be about 105 cases per 1000 livebirths (Leonard et al., 1983). Trace metals should be considered as one of the factors for such defects; the genotoxic effects of heavy metals actually include gene mutations, chromosomal aberrations, lesions in DNA, increases in the frequency of sister-chromatid exchanges, impairment of spindle formation, etc. (Babich et al., 1985). Furthermore, heavy metals can alter the constitution, function and fidelity of DNA synthesis and replication; can inhibit DNA and RNA biosynthesis; and can interfere with DNA repair, and with RNA crosslinkage and pairings, etc. (Jennette, 1981). Metals also play pivotal roles in membrane transport processes, redox functions, hydrolytic processes and in the activation of the macromolecules (Martell, 1981). Exposure to elevated levels of trace metals in the environment, clearly represents a genetic hazard to human beings but the magnitude of this problem remains to be determined.

\section{Immune suppression and allergies}

The effects of metals on these diseases has received little scientific study. Nevertheless, several studies have demonstrated that exposure to a number 
of heavy metals can render test animals highly șusceptible to endotoxins and infectious agents (EPA, 1986). Metal-induced immuno-suppression often occurs at low doses which elicit no evident toxicity in the organism. In the absence of hard scientific data, one can only speculate on the possible role of trace metals in the increasing number of people who are reportedly coming down with allergies, colds and other viral infections. Immuno-suppressive metals can also enhance the activity of other environmental carcinogens or their metabolic derivatives.

\section{Cancer}

At least 18 metals and metalloids and/or their compounds have been shown to be initiators or promoters of carcinogenic activity in animals: the metals are $\mathrm{Al}, \mathrm{Sb}, \mathrm{As}, \mathrm{Bi}, \mathrm{Be}, \mathrm{Mn}, \mathrm{Ti}, \mathrm{Cd}, \mathrm{Cr}, \mathrm{V}, \mathrm{Co}, \mathrm{Cu}, \mathrm{Fe}, \mathrm{Pb}, \mathrm{Ni}, \mathrm{Se}, \mathrm{La}$ and $\mathrm{Zn}$ (Jennette, 1981; Babich et al., 1985). In general, the assessment of carcinogenicity to a suspected metal or its compounds has been limited to high levels of exposure in the workplace environment or as a result of accidental spills or food contamination (Nordberg and Andersen, 1981). Current evidence that metal pollution induces cancer in the general population, is scanty and inconclusive (Nordberg and Andersen, 1981). However, the debate has not properly addressed two key issues (a) the possible effects of widespread low level exposures to a mixture of carcinogenic contaminants (Fern, 1971; Blumer and Reich, 1980; Nisbet and Karch, 1983), and (b) immuno-suppression caused by toxic metals and its role in cancer induction and metastasis. The genotoxicity of heavy metals has already been noted. It would appear that exposure to elevated levels of carcinogenic metals in the environment can induce cancer in a small number of the most susceptible individuals. The exact number of cases remains indeterminate on the basis of currently available scientific evidence.

\section{REFERENCES}

Adriano, D. C. (1986). Trace elements in the terrestrial environment. New York, Springer-Verlag.

Andreae, M. O. et al. (1984). Changing biogeochemical cycles. In: Changing metal cycles and human health, ed. by J. O. Nriagu, 359-73. Berlin, Springer-Verlag.

Asami, T. (1984). Pollution of soils by cadmium. In: Changing metal cycles and human health, ed. by J. O. Nriagu, 95-111. Berlin, Springer-Verlag.

Babich, H., Devanas, M. A. \& Stotzky, G. (1985). The mediation of mutagenicity and clastogenicity of heavy metals by physicochemical factors. Environ. Res., 37, 253-86.

Bell, J. U. \& Thomas, J. A. (1980). Effects of lead on mammalian reproduction. In: Lead toxicity, ed. by R. L. Singhal and J. A. Thomas, 169-85. Baltimore, Urban \& Schwarzenberg. 
Blumer, W. \& Reich, Th. (1980). Leaded gasoline-a cause of cancer. Environ. Internat., 3, 465-71.

Borella, P., Bergomi, M., Fantuzzi, G., Rovesti, S. \& Vivoli, G. (1987). Cadmium, zinc, and copper in hypertension. In: Proc. 6th International Conference on Heavy Metals in the Environment, Vol. 2, 89-91. Edinburgh, CEP Consultants.

Bowen, H. J. M. (1979). Environmental chemistry of the elements. New York, Academic Press.

Buat-Menard, P. E., Peterson, P. J., Havas, M., Steinnes, E. \& Turner, D. (1987). Group report on arsenic. In: Lead, mercury, cadmium and arsenic in the environment, ed. by T. C. Hutchinson \& K. M. Meema, 43-8, Chichester, Wiley.

Calabrese, E. J. (1983). Role of epidemiologic studies in drinking water standards of metals. Environ. Health Perspect., 52, 99-106.

Callahan, D. (1977). Health and society: some ethical imperatives. Daedalus, 106, 23-33.

Carmignani, M., Boscolo, P., Ripanti, G. \& Finelli, V. N. (1983). Effects of chronic exposure to cadmium and/or lead on some neurohumoral mechanisms regulating cardiovascular function in the rat. In: Proc. 4th International Conference on Heavy Metals in the Environment. 557-8. Edinburgh, CEP Consultants.

Carroll, R. E. (1966). The relationship of cadmium in the air to cardiovascular disease rates. J. Am. Med. Assoc., 198, 267-9.

CDC (1985). Preventing lead poisoning in young children. A statement by the Center for Disease Control, US Dept. of Health and Human Services, Atlanta, Georgia, January, 1985.

Clarkson, T. W. (1984). Mercury. In: Changing metal cycles and human health, ed. by J. O. Nriagu, 285-309. Berlin, Springer-Verlag.

Der, R., Fahim, Z. \& Yousef, M. (1976). Environmental interaction of lead and cadmium on reproduction and metabolism of male rats. Trace substances in environmental health, 10, 505-17.

DHHS (1982). Blood lead levels for persons 6 months-74 years of age: United States, 1976-80. Public Health Service, National Center for Health Statistics, US Department of Health and Human Services, Hyattsville, Maryland.

Drasch, G. A. (1983). An increase of cadmium body burden for this century-an investigation on human tissues. Sci. Total Environ., 26, 111-19.

Driscoll, C. T. (1985). Aluminum in acidic surface waters: chemistry, transport and effects. Environ. Health Perspect., 63, 93-104.

EPA (1986). Air quality criteria document for lead. Environmental Criteria and Assessment Office, US Environmental Protection Agency, Research Triangle Park, North Carolina.

Fern, V. H. (1971). The synteratogenic effect of lead and cadmium. Experientia, 25, 56-7.

Friberg, L. F. \& Vahter, M. (1983). Assessment of exposure to lead and cadmium through biological monitoring of a UNEP/WHO global study. Environ. Res., 30, 95-123.

Friberg, L. et al.(1984/85). Cadmium and health: A toxicological and epidemiological appraisal. CRC Press, Boca Raton, Florida.

Hickey, R. J., Schoff, E. P. \& Clelland, R. C. (1967). Relationship between air pollution and certain chronic disease death rates. Arch. Environ. Health, 15, $728-38$. 
Hutton, M. (1982). Cadmium in the European Community. MARC Report No. 26, Monitoring and Assessment Research Centre, Chelsea College, University of London.

Jackson, R. (1985). Issues in preventive health care. Discussion Paper, Science Council of Canada, Ottawa.

Jennette, K. W. (1981). The role of metals in carcinogenesis: biochemistry and metabolism. Environ. Health Perspect., 40, 233-52.

Kjellstrom, T. E. \& Nordberg, G. F. (1978). A kinetic model of cadmium metabolism in human being. Environ. Res., 16, 248-69.

Kjellstrom, T. E. et al. (1984). Perspectives and prospectives on health effects of metals. In: Changing metal cycles and human health, ed. by J. O. Nriagu, 407-23. Berlin, Springer-Verlag.

Kloke, A., Sauerbeck, D. R. \& Vetter, H. (1984). The contamination of plants and soils with heavy metals and the transport of metals in terrestrial food chains. In: Changing metal cycles and human health, ed. by J. O. Nriagu, 113-41. Berlin, Springer-Verlag.

Lansdown, R. \& Yule, W. (1986). Lead toxicity. Baltimore, Johns Hopkins University Press.

Levin, R. (1987). Reducing lead in drinking water: A benefit analysis. Office of Policy Planning and Evaluation, US Environmental Protection Agency, Report No. EPA-23-09-86-019, Washington, DC.

Leonard, A., Jacquet, P. \& Lauwerys, R. R. (1983). Mutagenicity and teratogenicity of mercury compounds. Mutat. Res., 114, 1-18.

Lewis, S. C., Forney, A. B. \& Forney, R. B. (1976). Correlation of lead and cadmium in human urine. J. Forensic Sci., 21, 150-3.

Mahaffey, K. R., Annest, J. L., Roberts, J. \& Murphy, R. S. (1982). National estimates of blood lead levels: United States, 1976-1980. New England J. Med., 307, 573-9.

Martell, A. E. (1981). Chemistry of carcinogenic metals. Environ. Health Perspect., 40, 207-26.

Moore, J. W. and Ramamoorthy, S. (1984). Heavy metals in natural waters. New York, Springer-Verlag.

Mosher, W. D. (1980). Reproductive impairments among currently married couples: United States, 1976. Advanced Data from Vital and Health Statistics, National Center for Health Statistics, US Department of Health, Education and Welfare, Washington, DC.

Murthy, L., Highhouse, S., Levin, L., Menden, E. E. \& Peterring, H. H. (1975). A study of the combined toxic effects of oral cadmium and lead in rats. Trace Substances in Environ. Health, 9, 395-401.

NAS (1979). Geochemistry of water in relation to cardiovascular disease. Washington, DC, US National Academy of Sciences.

NAS (1980). Lead in the Human Environment. Washington, DC, US National Academy of Sciences.

Nisbet, I. C. T. \& Karch, N. J. (1983). Chemical hazards to human reproduction. Park Ridge, New Jersey, Noyes Data Corporation.

Nogawa, K. (1981). Itai-Itai disease and follow-up studies. In: Cadmium in the environment, Vol. II, ed. by J. O. Nriagu, 1-37. New York, Wiley.

Nogawa, K. (1984). Cadmium. In: Changing metal cycles and human health, ed. by J. O. Nriagu, 275-84. Berlin, Springer-Verlag. 
Nomiyama, K. (1981). Renal effects of cadmium. In: Cadmium in the environment, Vol. II, ed. by J. O. Nriagu, 643-89. New York, Wiley.

Nordberg, G. F. \& Andersen, O. (1981). Metal interactions in carcinogenesis: enhancement, inhibition. Environ. Health Perspect., 40, 65-81.

Nriagu, J. O. (Ed.) (1978). Biogeochemistry of lead in the environment, Vols I \& II. Amsterdam, Elsevier.

Nriagu, J. O. \& Davidson, C. I. (Eds) (1986). Toxic metals in the atmosphere. New York, Wiley.

Nriagu, J. O. \& Pacyna, J. M. (in press). Global contamination of air, water and soils with trace metals-quantitative assessment, Nature.

Patterson, C. C. (1980). An alternative perspective. In: Lead pollution in the human environment, 265-349. Washington DC, US National Academy of Sciences.

Perl, D. P. (1985). The relationship of aluminum to Alzheimer's disease. Environ. Health Perspect., 63, 149-54.

Pershagen, G. (1983). The epidemiology of human arsenic exposure. In: Biological and environmental effects of arsenic, ed. by B. A. Fowler, Amsterdam, Elsevier.

Pirkle, J. L., Schwartz, J., Landis, J. R. \& Harlan, W. R. (1985). The relationship between blood lead levels and blood pressure and its cardiovascular risk implications. Am. J. Epidemiol., 121, 246-58.

Piscator, M. (1985). Dietary exposure to cadmium and health effects: impact of environmental change. Environ. Health Perspect., 63, 127-32.

Pocock, S. J., Shaper, A. G., Ashby, D., Delves, T. \& Whitehead, T. P. (1984). Blood lead concentration, blood pressure, and renal function. British Med. J., 289, $872-4$.

Roels, H. A. et al. (1981). In vivo measurements of liver and kidney cadmium in workers exposed to this metal: its significance with respect to cadmium in blood and urine. Environ. Res., 26, 217-40.

Rosen, J. F. (1985). Metabolic and cellular effects of lead: a guide to low level lead toxicity in children. In: Dietary and environmental lead: Human health effects, ed. by K. R. Mahaffey, 157-85. Amsterdam, Elsevier.

Schroeder, H. A. (1965). Cadmium as a factor in hypertension. J. Chron. Dis., 18, $647-56$.

Schwartz, J. (1986). The relationship between blood lead levels and blood pressure. In: Health effects of lead, 379-414. Commission on Lead in the Environment, Royal Society of Canada, Toronto, Canada.

Schwartz, J., Leggett, J., Ostro, B., Pitcher, H. \& Levin, R. (1984). Costs and benefits of reducing lead in gasoline. Washington, DC, Office of Policy Analysis, US Environmental Protection Agency.

Sherwin, R. P. (1983). What is an adverse health effect? Environ. Health Perspect., 52, $177-82$.

Thomas, R. D. (Ed.) (1986). Drinking water and health, Vol. 6. Washington, DC, US National Academy of Sciences.

Tseng, W. P. (1977). Effects and dose-response relationships of skin cancer and blackfoot disease with arsenic. Environ. Health Perspect., 19, 109-19.

Tsuchiya, K. (Ed.) (1976). Cadmium studies in Japan. Amsterdam, Elsevier.

WHO (1977). Environmental Health Criteria 3: Lead. Geneva, World Health Organization.

WHO (1981). Environmental Health Criteria 18: Arsenic. Geneva, World Health Organization. 
Wong, P. T. S., Chau, Y. K. \& Patel, D. (1982). Physiological and biochemical responses of several freshwater algae to a mixture of metals. Chemosphere, 11, $367-76$.

Zeise, L., Wilson, R. \& Crouch, E. A. C. (1987). Dose-response relationships for carcinogens: A review. Environ. Health Perspect., 73, 259-308. 